Some notable birds in both new National Parks are the lesser adjutant Leptoptilos javanicus, and wreathed Rhyticeros undulatus, rufous-necked Aceros nipaensis and great pied Buceros bicornis hornbills. Austen's brown hornbill Anorrhinus austeni and the pale-capped pigeon Columba punicea occur in Dihing-Patkai.

ANWARUdDIN CHOUdHURY (৫) orcid.org/0000-0003-25778938) The Rhino Foundation for Nature in North East India, Guwahati, Assam, India, and IUCN Species Survival Commission Specialist Groups (Asian Rhino, Asian Elephant, Asian Wild Cattle, Bear, Cat, Primate, Galliformes, Threatened Waterfowl)

E-mailacbadru56@gmail.com

This is an Open Access article, distributed under the terms of the Creative Commons Attribution licence CC BY 4.0.

\section{The first confirmed pregnancy of a released Amazonian manatee}

The Amazonian manatee Trichechus inunguis is a freshwater sirenian categorized as Vulnerable on the IUCN Red List. Since 2008, the Instituto Nacional de Pesquisas da Amazônia (National Institute of Amazonian Research) of Brazil with the support of the Associação Amigos do Peixe-boi (Friends of the Manatee Association) has been releasing rehabilitated manatees in the wild as a strategy for the conservation of this endemic species. The programme's indicators of success are: (1) exploration of the area by the released manatees, (2) selection of suitable habitats, (3) survival over at least one complete river flood pulse, (4) interaction with wild manatees, and (5) absence of contact with humans. Because of the difficulty of detecting manatees, breeding is not included in this evaluation.

During 2008-2019, a total of 35 rehabilitated manatees were released in the Brazilian Amazon. Twenty-two (63\%) with a VHF transmitter were monitored by trained ex-hunters for up to 752 days; $74 \%$ of the monitored manatees adapted successfully to the wild. To evaluate the health of the released manatees, recaptures are attempted during the dry season, involving biologists, veterinarians and fishers. Individuals are located using the VHF signal and, if the location is suitable, such as a small, shallow lake, the individual is surrounded by specially designed nets. Once captured, the manatee is transferred on a stretcher to the margin of the lake for collection of biometric data and blood and faecal samples.

Four manatees have been recaptured 6-18 months after release (one in 2016, one in 2017, and two in 2019). They had a mean increase of $45 \mathrm{~kg}$ in body mass and $10 \mathrm{~cm}$ in total length. One of the manatees recaptured in 2019 was Baré, a female rescued as an orphan calf and kept in captivity for 16 years. After 18 months in the wild, she had increased by $12 \mathrm{~cm}$ in length and gained $106 \mathrm{~kg}$. The large abdominal volume and vulvar oedema suggested an advanced pregnancy, later confirmed by serum progesterone analysis. Barés pregnancy, and the participation of local people in the protection and monitoring of the manatees, confirms the success of the programme.

The lessons learnt will support future management planning for Amazonian manatees. In July 2021, Instituto Nacional de Pesquisas da Amazônia and Associação Amigos do Peixe-boi released 13 rehabilitated manatees, the largest group to date. Our experience shows that a combination of releases and environmental education activities is an effective conservation tool for the Amazonian manatee.

DiOgO DE SOUZA (৫ orcid.org/0000-0002-4896-7507) and José D’AFFonseCA NETo (৫ orcid.org/0000-0003-4508-1951) Associação Amigos do Peixe-boi, Presidente Figueiredo, Brazil.E-mail diogo.peixeboi@gmail.com

RODRIGO AMARAL (৫ orcid.org/0000-0002-0455-2481) Instituto Federal de Educação, Ciência e Tecnologia do Amazonas, Manaus, Brazil

VERA M.F. DA SILVA (๑ orcid.org/0000-0002-1774-0393) Instituto Nacional de Pesquisas da Amazônia, Manaus, Brazil

This is an Open Access article, distributed under the terms of the Creative Commons Attribution licence CC BY 4.0.

\section{Discovery of an intercontinental trade in porcupine bezoars from the Republic of the Congo}

Old world porcupines (family Hystricidae) are extensively hunted across the tropics for subsistence. Porcupine bezoars (undigested organic and inorganic material occurring in the stomachs of some individuals) are used in purported medicines in South-east Asia (Heinrich et al., 2020, Global Ecology and Conservation, 24, e01204). The African brushtailed porcupine Atherurus africanus, a common bushmeat species in Central Africa, has not previously been identified as a source of bezoars for the Asian market. In September 2020, we discovered signs of the trade in the south-west Republic of the Congo through interviewing local bushmeat sellers along the RN1 national road near the town of Dolisie. The sellers confirmed the occasional presence of bezoars in porcupines and showed us one, offering it for USD 36 per g. They provided information about the supposedly Chinese purchasers of their stocks, who reside in Dolisie, where we later approached a group comprising one Congolese man and two male logging company managers of Malaysian citizenship (from Sarawak). They showed us bezoars of various sizes, the largest being c. 200 g. Bezoars are purchased by the men or their Congolese representatives in multiple villages, hunting areas and logging camps, and later hidden in their airline luggage and transported to 